\title{
$4 \quad$ Burmese Female Migrant Workers in Thailand: Managing Productive and Reproductive Responsibilities
}

\author{
Kyoko Kusakabe ${ }^{1}$ and Ruth Pearson ${ }^{2,3}$
}

\begin{abstract}
This case study argues that even in increasingly unstable circumstances women migrant workers have to continue to balance their reproductive responsibilities as mothers and daughters with their ongoing roles as wage workers and economic providers, often managing complex transborder care arrangements. The chapter extends the global care chain framework to investigate the ways in which Burmese migrant factory workers in Thailand organize reproduction and childcare in the place of destination and in the in-between places at the international borders between the two countries. The chapter provides new insights into ways migrant women factory workers adapt and strategize to achieve daily, generational, and biological reproduction needs and the links between these strategies and the pattern of capital accumulation in Thailand's border industrialization strategy. The elaboration of multiple forms of control and regulation from the state to the factory as well as community highlights the structures of constraint as well as the ways women negotiate around these constraints. The aim of the chapter is to delineate key issues of social injustice relating to their nationality and legal ambiguity of status (migrant or worker). Focusing on the individual agency of migrant workers, our research demonstrates that existing analyses of the women's experiences of work and of harassment in Thailand needs to be supplemented by an understanding of their ongoing but changing connections with home and family, in terms of resourcing care for children, the elderly, and other relatives in their home country, as well as their community and family obligations and responsibilities in their place of employment.
\end{abstract}

Keywords: Women, migrant workers, Thailand, Burma/Myanmar ${ }^{4}$, social reproduction ${ }^{5}$, border factories, global care chains, nationality, citizenship, graduated sovereignty

\subsection{Introduction}

Over the last two decades it has become clear that the current phase of globalization has been marked not just by transborder trade and investment but also by international mobility of labour. But it is only in recent decades that academic and policy analysis has focused on women who migrate to seek employment, rather than on those accompanying other migrant

1 Kyoko Kusakabe is an associate professor at Gender and Development Studies, School of Environment, Resources and Development, Asian Institute of Technology, Pathumthani, Thailand.

2 Ruth Pearson is Professor of Development Studies at the School of Politics and International Studies, Faculty of Education, Social Sciences and Law, the University of Leeds, Leeds, United Kingdom. workers, though of course many women straddle both categories. A central focus of such research con-

3 This chapter is based on the research findings of the IDRC-funded project "Gender, Cross-border Migrant Workers and Citizenship: A case study of the BurmeseThai Border", project number I0385I-00I. It is an updated and expanded version of an article published in the International Migration Journal (See Kusakabe/ Pearson 20IO). It also draws on material discussed in Pearson/Kusakabe (20I2b). The research has been carried out with the support of Naw Htee Heh, Zin Mar Oo, Naw Eh Mwee, Cecil Khin. Also acknowledged are support from Kanokporn Jaroenrith, Lada Phadungkiati, San Sithilertprasit and Usamard Siampakdee. Support from MAP Foundation and its director Jackie Pollock, Yaung Chii Oo Workers' Association and Pattanarak Foundation were also indispensable for the completion of the research. 
cerns the links between the accumulation of capital and the processes and networks that provide for the reproduction of labour power-what feminists have termed social reproduction. This analysis focuses not just at the macro level on the structural causes and process of migration, but importantly on the micro level, which foregrounds the experiences, subjectivities, and agency of migrant women involved in globalizing production processes (see Silvey 2004).

This article explores how Burmese migrant women workers in Thailand negotiate conflicting responsibilities for the families they have left at home, for their new households formed in the Thai cities in which they now live, and for the paid work which is the purpose of their migration. It foregrounds women's agency and explores how migrant women workers negotiate with wider social and political structures (Parreñas 200I; Yeoh/Huang I998). This involves going beyond the analysis of the vulnerability to exploitation of migrant women workers, due to the lack of effective protection from either the sending or the receiving state, to analyzing the gendered implications of their responsibilities for reproduction (Thapan 2006: I3; Pearson/Kusakabe 20I2a). There is a continuous struggle between wage earners and the state to meet the resource and other costs of childcare and other reproductive responsibilities, which Pearson (1997) termed the 'reproductive bargain'. But when the state rolls back its responsibility for taking care of childcare, disabled and sick people, and increasingly, elderly people, it is most frequently women who have to extend their paid and unpaid work to ensure that any care deficit is covered. Very often this adjustment takes the form of unpaid work, which can restrict women's participation in the labour force, or the range of paid work which they can access, or both. Women's restricted participation can have negative ef-

4 Burma is the name of the country, used since British colonial rule. However, it was renamed by the ruling military junta as the Union of Myanmar in 1989 and in $20 I I$ the Republic of the Union of Myanmar. The name remains contested. The UN has endorsed the name 'Myanmar' although many governments still refer to the country as Burma. Media outlets have a mixed practice. Opposition groups, especially non-Burman ethnic groups refuse to recognise the new name because the term "Myanmar" has historically been deployed only by majority Burman ethnic group. Our practice is to retain the name 'Burma' which is universally used by migrant workers in Thailand in the English-speaking media and academia but we use Burma/Myanmar when referring to official treaties, documents or government actions where relevant fects on the economy, which in many cases has pressured the state to rethink its support for care, as is the case in contemporary Japan (Osawa 20II).

The situation for migrant workers in terms of support for childcare and other reproductive responsibilities is generally worse than for other workers. In most situations neither the state of origin nor the destination state takes any responsibility for the childcare needs of women migrant workers, who are usually excluded from any entitlements available to national citizens. Destination states consider migrant workers as only temporary residents in the country, so see no reason to invest in the reproduction of the next generation; and sending states, even those which sponsor the outmigration of women workers, are more interested in the repatriation of remittances from migrant earnings than in contributing to their childcare costs, particularly when the children are raised in another country. So most migrant workers are left to organize and finance the costs of bearing and raising their own children from their own resources without state or other support. In the face of this situation, which is coupled with low bargaining power as workers, and often indifference or even hostility from the receiving state, migrant workers actively mobilize their family and other networks in order to juggle their care responsibilities with the demands of their paid employment, in spite of the harsh environment they find themselves in.

This is the situation for Burmese migrant women in our study who are employed in the garment and textile factories in the border areas of northern Thailand, and are involved simultaneously in reproductive as well as productive work. The micro-level analysis of their experience enables an understanding of the ways in which migrant women's reproductive (domestic) labour is linked to the global economy. An important focus of recent research has been on 'global care chains', which describe the transborder commoditization of care work resulting from the migration of domestic and other care workers, mainly from low-wage developing economies of the global South to the industrialized economies of the North (Hochschild 200I; Yeates 2005; Sassen 2008). Our research extends this analysis by demonstrating how care work and global production are also linked by the reproductive work of women migrant factory workers who are employed in other sectors of the economy, but who still retain the responsibility to resource, organize, and often deliver care work for their own families, including their parents and siblings as well as their own children. ${ }^{5}$ 
This chapter analyses the experience of Burmese migrant women workers in Thailand, looking at the structure of constraints within which they have to exercise individual agency, particularly concerning the issue of social reproduction, that is, not just biological reproduction but also the reproduction of labour power as daily and generational processes (Mackintosh 1984; Folbre 1994). The existing literature on migrant workers in Thailand has provided a detailed, if grim, picture of the exploitative conditions where migrants work, mainly in the agricultural, construction, and manufacturing sectors. ${ }^{6}$ Attention has also been paid to the ways in which migrant workers' labour rights and human rights have been continually violated by immigration officials and the police and the military in Thailand. Our research takes this analysis further by demonstrating that the workers' experiences of work and of harassment in Thailand needs to be supplemented by an understanding of their connections with home and family, in terms of resourcing care for children, the elderly, and other relatives in their home country, as well as their community and family obligations and responsibilities in their place of employment. Their experiences are also shaped by the ways in which migrant workers have been regulated and controlled within Thailand historically, through a series of registration exercises seeking to "regulate irregular migration" (Traitongyoo 2008), which offer very temporary permission for 'illegal migrants' to remain in Thailand to work in specified jobs and economic sectors. Although the situation for migrant workers in Thailand has recently become more regulated with the introduction of temporary passports and work permits as the result of memoranda of un-

5 For a more theoretical treatment of this point see Pearson and Kusakabe (20I2a).

6 World Vision/Asian Research Center for Migration (2003); Institute of Asian Studies/Thailand Development Research Institute/Institute for Population and Social Research (2003); Thammasak (1998); Arnold (2004, 2006); FTUB (2004); FTUB Migrants Section/ Robertson Jr. (2006); Amnesty International (2005); Hveem/Than Doke (2004); Pearson/Punpuing/Jampaklay/Kittisuksathit/Prohmmo (2006); Chulalongkorn University (2003); Asian Human Rights Commission (2005); Asian Research Center for Migration/Institute for Population and Social Research/Thailand Development Research Institute (2004); Caouette (200I); Huguet/Punpuing (2005); Martin/Asian Research Center for Migration/Institute for Population and Social Research/Thailand Development Research Institute (2004); Myint/ Bhumiprabhas/ Kerdmongkol (2004); Pollock (2006); Punpuing 2006. derstanding (MOU) with neighbouring countries, migrant workers in Thailand remain in a precarious situation. Indeed in some respects their situation has deteriorated - for instance, workers registering under the previous system were covered by compulsory health insurance, ${ }^{7}$ but under the temporary passport and work permit system, migrants have to purchase private health insurance for themselves and employers no longer have any obligation to provide health insurance for them.

Migrants' opportunities and constraints are also affected by the national and bilateral citizenship and nationality regimes in both Burma (Myanmar) and Thailand, which have become more institutionalized with the introduction of the bilateral MOU in 2003, although this was not implemented until 2009-IO. At the same time, women face gendered constraints on mobility, enforced both by the gender regimes of their communities of origin and destination and by the factory owners and the police and immigration authorities in Thailand. And in spite of the fact that the majority of the migrant workers in this case study are of prime reproductive age, political discourses which construct Burmese migrants as polluting and problematic, as well as their economic constraints and lack of access to health care, education, and citizenship rights, all serve to further constrain these women's reproductive choices and practices. While it is widely acknowledged that global competition since the I970s has frequently been based on the search for cheap labour, the gendered ways in which transnational reproductive labour is performed reflect "the ways in which the globalization of the market economy has extended the politics of reproductive labour into an international arena" (Parreñas 200I: 62).

At the same time, as this chapter illustrates, the politics and policies of globalized production and labour markets reach down through regional and national policy arenas into the households and families of the migrant workers themselves. This chapter therefore seeks to explore these issues by tracing the connections between the experiences of transborder migration from Burma to Thailand of women factory workers in the context of the economic policies and strategies of the Thai government and a rapidly globalizing world. This chapter is organized as follows: the next section sets out the context of the case study research, and the details of the research methodology and data collected in the study. This is followed by a discussion of the regulation and control of Burmese

7 Bangkok Post, I3 May $20 \mathrm{I2}$. 
migrants working in the export factories of Mae Sot, in Tak Province, and the constraints on women workers' mobility. The subsequent sections set out the ways in which the costs of reproduction of labour, daily and generational as well as biological, are borne directly by woman workers who have to resource, and often deliver, the labour required to care for children and dependent elderly parents from a wage earned in precarious and often exploitative employment. Together these processes ensure that Thai factories have access to cheap migrant labour.

\subsection{Research Methodology and Context}

The location of this study was the border between Thailand and Burma: the town of Mae Sot, in the Thai province of Tak. Mae Sot has been designated for development by the government of Thailand, and was named in the context of the twin border cities included in the Bagan Declaration for mutual cooperation and development. ${ }^{8}$ The town has grown since the early I990s and is one of the areas in Thailand which has witnessed a rapid growth in migrant workers from different parts of Burma. Mae Sot is also the location of a large number of export garment and textile factories, many of which have relocated from other parts of Thailand, and which employ virtually roo per cent migrant Burmese workers. These factories range from large industrial enterprises with a workforce of up to two and a half thousand, to small "house factories" with a few dozen workers. Most of the factories are Thai-owned, and many are subcontractors for East Asian or Western supply chains producing for the international market.

This study draws on eighty in-depth interviews with migrant workers (sixty-eight women and twelve

8 The Bagan Declaration, adopted November 2003, states the intention of the four countries involved - Myanmar, Thailand, Laos, and Vietnam - to collaborate on a range of development projects over the following decade (in: Myanmar Times, I7-23 November 2003; at: <http:// www.mmtimes.com>) and was followed by a series of bilateral projects aimed at strengthening regional economic integration and border area development (Tsuneishi 2005). The stated aims of this bilateral cooperation are not only to facilitate flows of goods and investment, but also to reduce socio-economic disparities. Thailand pledged Ioo million baht (US\$ 2.5 million) for 2004 and 2005 , and was considering earmarking 10 million baht over a period of five years (ACMECS 2004). men) carried out by Burmese members of our research team in Mae Sot between June 2007 and December 20I0, as well as a semi-structured questionnaire survey of 302 migrant workers (women 2II, men 9I). Participatory workshops were also organized with male and female Burmese migrants as well as interviews with a number of migrant workers' organizations and individuals in Mae Sot between 2007 and 2009. The migrant worker interviews covered life histories, work histories, and working conditions and aspirations. This involved the researchers spending time in pagodas, libraries for migrant workers, and health clinics and hospitals, where they were able to get to know migrant workers and establish rapport with them and engage in informal discussions. The researchers conducted longer in-depth interviews with some of the workers who indicated that they were willing to talk at more length. By basing themselves for several weeks at a time in Mae Sot, the interviewers were able to build up relationships of trust with many of the interviewees, and make the acquaintance of more migrant workers through a snowballing methodology based on these workers' networks.

The semi-structured questionnaires were administered with the help of Yaung Chi Oo Workers Association (YCOWA) in Mae Sot. Rather than attempt to construct a representative structured sample, which was not possible because of the research context, which did not allow access to workplaces and lacked any reliable statistical data, the methodological approach taken was purposive sampling. Employees at specific garment factories were targeted based on the connections that YCOWA had within particular factories. The survey focused on married women and married men who had been working in Thailand for more than three years at the date of interview.

In addition, the research used secondary data, including academic studies and reports from both Thai and international NGOs and migrant organizations. It also drew on two workshops held in Mae Sot in July 2007 , one for representatives of organizations working with migrant workers, and one for factory workers themselves (Kusakabe/Pearson/Naw Eh Mwee/ Phadungkiati 2008).

The demographic profile of our respondents is detailed in table 4.I. It should be noted that the education level of migrant workers is not necessarily low, with most workers having completed primary school and many with secondary education or above. Many of our respondents were single when they initially came to Mae Sot, but had married since starting to work in the factories there. More than seventy per 
Table 4.1: Demographic profile of respondents in Mae Sot. Source: Authors' analysis of semistructured questionnaire.

\begin{tabular}{|c|c|c|}
\hline & Women & Men \\
\hline Average age & 29.77 & 29.81 \\
\hline $\begin{array}{l}\text { Average years of } \\
\text { schooling }\end{array}$ & 7.23 & 8.71 \\
\hline Marital status & $\begin{array}{r}\text { Married: } 89.6 \% \\
\text { Divorced: } 8.1 \% \\
\text { Remarried: } 1.4 \% \\
\text { Widow: } 0.9 \%\end{array}$ & $\begin{array}{l}\text { Married: } 94.5 \% \\
\text { Divorced: } 5.4 \%\end{array}$ \\
\hline $\begin{array}{l}\text { Number of } \\
\text { children }\end{array}$ & \multicolumn{2}{|c|}{$\begin{array}{l}\text { One child: } 75.2 \% \\
\text { ( } 227 \text { respondents) } \\
\text { Two children: } 21.9 \% \\
\text { ( } 66 \text { respondents) } \\
\text { Three children: } 2.3 \% \text {, } \\
\text { (7 respondents) } \\
\text { Four children: } 0.3 \% \\
\text { (1 respondent) } \\
\text { Five children: } 0.3 \% \\
\text { ( } 1 \text { respondent) }\end{array}$} \\
\hline Ethnicity & $\begin{array}{r}\text { Burman: } 78.2 \% \\
\text { Karen: } 11.4 \% \\
\text { Mon: } 8.5 \% \\
\text { Others: } 1.9 \%\end{array}$ & $\begin{array}{r}\text { Burman: } 90.6 \% \\
\text { Karen: } 1.2 \% \\
\text { Mon: } 3.5 \% \\
\text { Others: } 4.7 \%\end{array}$ \\
\hline
\end{tabular}

Based on questionnaire interview with 211 women and 91 men.

cent of the women migrant workers surveyed in Mae Sot gave birth to their first child after coming to Thailand.

The information gathered from these sources complements a range of previous studies which have documented the working conditions of Burmese migrant workers in Mae Sot's border factories (Arnold 2004, 2006; FTUB 2004; FTUB/Robertson Jr. 2006; Pollock 2006). The information derived from the workshops and interviews was triangulated with the views of key specialists within Thailand, particularly from NGOs and the Thai academic community. This allowed us to construct a more holistic understanding of the ways in which Burmese migrant women workers juggled their reproductive responsibilities with the demands and constraints arising from their working lives within the factories, and dealt with the gendered restrictions and constraints they faced in terms of the labour regimes within the factories, as well as the immigration regulations and restrictions on their mobility and entitlements within Thailand. These are discussed in the following section.

\subsection{Regulation and Control of Migrant Factory Workers in Thailand's Border Areas}

\subsubsection{Creating 'Cheap Labour' for Thailand's Export Industries}

Factories in Thailand have responded to growing global competition in export markets by seeking to reduce labour costs through the utilization of "cheap" migrant labour. As has been extensively noted by previous research on export sectors that involve manual operations, women have historically provided the most productive source of cheap labour, and their low unit costs of production are routinely attributed to their 'natural' attributes as unskilled, docile, and secondary (and therefore disposable) labour (Elson/Pearson I98I; Wright 2006). But they are also cheap in terms of the ways in which the capital that employs them, and the state in which they are situated, are able to avoid any contribution to the costs of reproduction of their daily labour power and the generational reproduction of the workforce. In Thailand as elsewhere, migrant workers are particularly vulnerable to exploitation in the form of below-standard wages and poor working conditions since they are generally not protected by labour regulation or citizenship rights. Moreover, they also subsidize capital and the state through the complex ways in which they manage their gendered reproductive responsibilities for securing housing, food, education, and health care and caring for children and elderly and disabled family members (Nagar/Lawson/McDowell/Hanson 2002). Burmese women migrant workers constitute an especially vulnerable and exploitable source of 'cheap labour' in manufacturing. Whilst in other contexts export factories have migrated to cheap labour platforms, for example from the United States to northern Mexico or the Asian Newly Industrialized Countries (NICs), in this instance Thai capital has remained in the country, whilst the cheap labour has migrated over the borders from Burma. Because of the economic and political repression in Burma (Fink 2009) and the limited rights of migrant workers within Thailand, Burmese women migrant factory workers are protected by neither their state of origin nor their state of destination, and, as has been extensively documented, are subjected to arbitrary and exploitative labour conditions including excessive hours of work, unhygienic living conditions, arbitrary deductions from their wages, and vulnerability to arbitrary dismissal, arrest, and deportation. 
Since the I990s, when the policy of employing migrant workers in Thailand's border industries took off, there has been a series of government measures aimed at exercising some control over the influx of transborder migrants into the country, a process frequently seen as "regulating the irregular" (Traitangyoo 2008). Regulation has sought to reconcile two competing concerns: the fear of migrants' bringing disease, criminality, and political unrest into the Thai polity, and the expressed desire of government and industrialists alike to access cheap labour in order to export to an increasingly competitive market where labour-intensive products such as garments and footwear face strong competition from emerging economies in the region, particularly China and Vietnam, who are able to undercut Thailand on the basis of lower labour costs. According to Chalamwong (2004), the Thai government's creation of a formal category of "registered irregular migrant workers", who are granted legal permission to work for a set and limited period of time, gives the utmost flexibility. Because they retain their illegal status, registration represents only a stay of execution of their expulsion and allows the government to deport them when their period of registration expires. This formula provides an opportunity for Thai industries to access cheap immigrant labour and offers government a source of revenue from migrant registration fees while at the same time enabling it to maintain a policy of controlling immigration and denying Thai citizenship to a range of foreign workers. The creation of this category of 'irregular' migrants reflects what Sparke, Sidaway, Bunnell, and Grundy-Warr (2004) have described as a "a clever remedy", whereby the state creates a regulatory framework which allows it ${ }^{9}$ to mete out different treatment to different segments of its population, allowing the market to benefit from such an arrangement.

As noted above, potential migrant workers are officially required to go through a verification of nationality in their country of origin and then apply for temporary passports and obtain a permit to work in Thailand. The permit is given for two years with the possibility of a single extension of two years. But this kind of official state-to-state agreement does not necessarily make the lives of migrants from Burma to Mae Sot any easier. On the contrary, many feared that

9 See MAP Foundation website on: "The regulation of migrant workers following the MOUs"; at: <http:// www.mapfoundationcm.org/Eng/MOUupdate/html> (accessed 3 April 2009). the nationality verification would make them more vulnerable because of the prevailing political situation in Burma. They were particularly afraid that their families back home would be harassed by the authorities, through higher tax collection and so on, if they gave Burmese officials information about their villages of origin. ${ }^{10}$ Even though the current moves towards greater democracy and political pluralism promise the legalization of trade unions and extension of workers' rights within Burma, such changes have not yet percolated through to the rural areas or the border states where ethnic minority groups are still fighting for autonomy. At the same time, although the MOU states that those who migrate under this process will enjoy a full guarantee of labour rights equal to those of Thai workers (FTUB/Roberston Jr. 2006), there is little confidence amongst the migrants that this is feasible or even possible. In fact the procedure is so complicated that workers are having to rely on so-called 'agents' to obtain temporary passports on their behalf, and this involves considerable expenditure, doubling the officially quoted fee for obtaining nationality verification of I,050 baht. ${ }^{11}$ Some migrant workers who opt to manage the process without the employer's help have hired agents to go through the process for them and have reported paying up to seven to ten times more than the official rate.

Meanwhile the flow of migrant workers to Thailand continues, though an increasing proportion remains outside any regulatory framework. There are no reliable estimates for the total number of migrant workers in Thailand. Martin (2007: 4), citing Rattanavut (2006) and Huguet (2007), estimated that in 2006, there were I.8 million foreign workers in Thailand, of which twenty-six per cent were registered. Other estimates have put the number much higher and figures of between 2 and 2.5 million are frequently cited (FTUB/Robertson Jr. 2006), with over sixty per cent from Burma. Of the registered Burmese migrants, 46.I per cent are women ${ }^{12}$. As of March 20II, there were 350,9I5 migrant workers who went through the nationality verification process (of which I59,662, or 45.5 per cent, were women), while a total

10 MAP Foundation website "The regulation of migrant workers following the MOUs"; at: <http://www.mapfoundationcm.org/Eng/MOUupdate/html> (accessed 3 April 2009).

11 Bangkok Post, I3 April 2012.

12 See MAP Foundation - No migrant worker is illegal website on: "Registration for migrant worker permit I996-2008”, at: <http://www.mapfoundationcm.org/ news/registration_new.html> (accessed 3 April 2009). 
of 394,903 workers were still in the registration process (including 179,779 women). ${ }^{13}$ However, in Tak province, where Mae Sot is located, only 889 workers completed the nationality verification process (44I women), with a further 22,538 (I4,9I7 women) who were registered. ${ }^{14}$ There is less incentive for employers to go through the cumbersome nationality verification process in a border town like Mae Sot, where the employers think it is easy to get away with not following the verification process, despite inspections-the workers can cross the border and wait on the Burmese side whenever necessary. So after the temporary passport was introduced, in Mae Sot the number of workers who have legal status in Thailand decreased.

The increased employment of migrant workers in the textiles and garments sector reflects the declining fortunes of in the industry particularly since the 19978 financial crisis in Thailand. From being the largest export item for many decades, textiles' share of exports had fallen to fifth place by 2003 , and had disappeared from the top ten export items by 2006 (EXIM 2006). The decline in export importance since the crisis paralleled a fall in employment share, though textiles still accounted for twenty per cent of the 5.4 million industrial workers (Barimbun 2006). Up to eighty per cent of the sector's employees are women, a proportion that has remained remarkably stable in the face of changes in overall employment in this sector (Chalamwong/Amornthum 2002). And since the I997 crisis, production of garments and textiles has shifted significantly to the border areas in the north, north-west, and north-east of Thailand, which have seen both a fall in real wages and an increase in the employment of migrant workers. The growth in the number of factories and in total employment in this sector has been especially dramatic in Tak province, where Mae Sot is located. ${ }^{15}$

13 See MAP Foundation website at: 〈http://www.mapfoundationcm.org/pdf/eng/number_Mar2oII.pdf $>$ (accessed 28 July 20I2).

14 See MAP Foundation website at: <http://www.mapfoundationcm.org/pdf/eng/number_Mar2oII.pdf> (accessed 28 July 20I2).

15 According to an interview with the Labour Office of the Tak province, the 1997-8 economic crisis in Thailand provided particular opportunities for the province. Since it borders Burma, it has access to a large quantity of cheap labour making it attractive for labour-intensive industries to consider relocation, a view which is reinforced by the dramatic increase in the number of workers and number of factories after the recovery from the from the shock of the economic crisis of 1997 (see figure 4.2).
In recent years the Thai government has maintained that the objectives of Thai development initiatives were to close the economic gap between Thailand and its poorer neighbours and to stem the inflow of foreign workers into Thailand. But if this was the case, these measures have demonstrably failed, and nowhere more so than in the area around Mae Sot. Although a plan to establish a Special Economic Zone in Mae Sot ${ }^{16}$ has never materialized, the employment of migrant workers has expanded in the area. Of the total of 92I,482 registered migrant Burmese workers in Thailand in 2004, $\mathrm{I} 24,6 \mathrm{I} 8$ or $\mathrm{I} 3.5$ per cent were registered in Tak Province (FTUB/Robertson Jr. 2006), making it the largest concentration of registered Burmese migrants outside Bangkok, ${ }^{17}$ and various sources suggest that this figure should be multiplied by a factor of two to three to account for the large number of unregistered workers. Such a high number of migrant workers in a relatively small border province reflects the success of the Thai government's policy of concentrating migrant workers in border areas. The number of manufacturing establishments in the area has also grown rapidly. According to FTUB and Robertson Jr. (2006), there were I24 officially registered factories in 2004 in Mae Sot; approximately twothirds (eighty factories) were apparel factories, and these employed over I4,000 workers. ${ }^{18}$ If informal and unregistered factories were included, the total number was estimated to be greater than 200 , again reflecting the real situation in the town whereby the registered factories represent less than half the total number of establishments that rely on a cheap migrant workforce.

Together with new industrial development policies which emphasize advantages for Thailand from cooperation with neighbouring regimes in the Mekong subregion, Mae Sot offers a site for Thai industrialists to seek maximum benefit from access to cheap cross-border migrant labour from Burma with

16 Special Economic Zones were originally proposed for cities such as Mae Sai and Mae Sot, which are along the economic corridors.

17 According to the Ministry of Labour, the number of registered Burmese migrant workers in Tak province in 2007 was 26,9II, of which I8,II5 were women (Sciortino/Punpuing 2009: 64). They estimated that in 2007, only twenty-seven per cent of migrants from Laos, Cambodia, and Burma were registered.

18 Ministry of Industry: "Accumulative number of the registered factories by province by type at the end of the year" data on 2006; at: <http://web.nso.go.th/en/survey/manuind/manufac.htm> (accessed 27 June 2007). 
few constraints on how that labour is recruited, deployed, respected, or remunerated. It is to these conditions of work and of life that we turn below.

\subsubsection{Restricting Women Migrant Workers' Mobility}

The high concentration of Burmese women workers in Mae Sot, and industry's need for cheap and 'disposable' labour, has led to practices which govern and restrict the movement of migrants in Mae Sot. The ways in which women migrant workers experience restrictions on their mobility comprise an aspect of the gendered nature of "graduated sovereignty" described by Ong (2000), whereby the state operates a system of differentiated regulation according to specific aspects - race, ethnicity, and nationality - of different sectors of the population. Many women interviewed for our research reported that they are, or perceived that they are, restricted to the factory compound and its immediate environs, unable to venture out into the town and beyond. The restrictions reflect different forms of constraint on workers' mobility. Firstly, many workers are expressly forbidden by the factory managers to leave the compound, except for specified occasions. One manager reported to us that the workers were like family and everything was provided for them; they had no need to leave the compound except for an afternoon once or twice a month.

Police spot checks and the regulation requiring work permits are further problems for workers moving about outside the factory. Registration documents indicate that a migrant is only permitted to remain within the province of registration; the authorities use this as a reason to check the papers of Burmese individuals, and this serves as a deterrent to workers' mobility. Even those who have registration papers are rarely able to keep the original; many of our interviewees reported that they were given only a photocopy of the document, which police usually rejected, and workers could be fined, imprisoned, or deported without the relevant papers. The restrictions apply to all workers, but they are experienced in a gendered manner. Figures from the Immigration Office in Mae Sot indicate that more men than women are deported back to Burma by the authorities, even though women comprise the vast majority of workers in the factories. In 2006, women comprised forty-two per cent of the 69,998 people deported from Mae Sot to Burma because of illegal entry. One male migrant worker reported that he had been arrested thirteen times by police in nine months. ${ }^{19}$ Our questionnaire survey indicates that male workers have had to pay off the police slightly more frequently than women (I.82 times per head, compared to women's rate of $\mathrm{I} .45$ ) and are also forced to pay a slightly higher amount than women (men pay I34.2 baht a time, while women pay I29.4 baht).

Explanations for this gender difference are that men tend to be out in the street at night and that they are viewed by the population at large, as well as the police, as a security threat. This leads to arrest and often violence not just from the police and immigration authorities, but also from groups of youths who are reported to roam the town harassing and threatening migrant workers. ${ }^{20}$ Women too are the objects of both physical and sexual harassment and violence from both police and local gangs. This makes women reluctant to take risks in the town. Indeed, we heard several reports of aggression from officials and local youths. Moreover, as is the case elsewhere, women, particularly recent migrants, tended to avoid risking such aggression and preferred to remain within the confines of the factory compound (see also Valentine 1989).

Many women and men get accustomed to being arrested and even deported, especially those who are involved in workers' organizations and can access training and advice from others. ${ }^{21}$ Moreover, some of the Burmese migrant workers, particularly those who had had several years' experience of living and working in Mae Sot, expressed some ambivalence about whether they felt they were worse off than they had been in their home country. Although they faced constraints on their mobility, those who had managed to negotiate some degree of freedom within the town valued the relative autonomy they had as workers in Thailand, in contrast to the strict nature of family and community vigilance and control which was particularly constraining for young women. However, this view was only expressed by those individuals who had

19 Interview, in: Mae Sot, 25 August 2007.

20 Ling (2007) noted such harassment by youth groups in Samut Sakorn, and our interviews in Mae Sot with migrant workers indicated that they are frequently targeted by groups of Thai youths.

21 This was reported by those participating in the NGO and Union workshop held in Mae Sot on 6 July 2007 (Kusakabe/Pearson/Naw Eh Mwee/Phadungkiati 2008). According to our informants from these organizations, this involved paying bribes to the police, alerting colleagues and employers to pay the authorities or produce appropriate documentation or both, and in some cases submitting to deportation and then re-crossing the border. 
gained confidence over a number of years, and who were involved in worker organizations or NGOs. ${ }^{22}$

\subsection{Gender and the Daily Reproduction of Labour Power}

Low wages and late payment of wages, long working hours, deduction of living costs from wages, restrictions on mobility, poor sanitary conditions in the workplace and in living quarters, and the confiscation of identity documents are all commonly cited as problems faced by workers. According to Punpuing (2006), migrant workers in Tak province earned only 50-80 baht ${ }^{23}$ per day, 38-69 per cent of the minimum wage in Tak province of 130 baht. The wage rate is much lower in Tak province compared with Bangkok where migrant wage rates are IOO-I20 baht a day, representing 55-66 per cent of the minimum wage of I80 baht. These figures reflect the higher proportion of migrant workers in the agricultural sector as well as the relative freedom of Tak factories to undercut minimum wages. Our questionnaire survey showed that the average daily wage for migrant workers in Mae Sot in 2008-9 was 97.8 baht compared with the official minimum wage of 157 baht during that period. ${ }^{24}$

Labour inspection officers said that it is difficult to detect the underpayment of wages, because on the books, workers are paid minimum wages, while the actual payment received by the workers is far lower, as we explore below. Many workers in Mae Sot work at piece rates, so that when orders are low this directly affects their level of earnings. Many workers reported that some factory owners gave workers twenty baht a day for food if there was no work, but the notion of any contractual obligation to pay workers was completely absent.

The calculation of migrant wages is invariably an overestimation. According to previous research, as well as our own interviews, the wages actually received by factory workers were well below the noti-

22 The women who talked about their relative autonomy were those who attended the workshop in July 2006 (see footnote 2I); interestingly, only a third of the delegates from these organizations who came to this event were women, reversing their representation in the Mae Sot factory labour force as a whole.

23 I baht $=$ US\$ 0.03 .

24 This does not include the earnings of workers who are paid at piece rate, who constitute around thirty per cent of the total respondents. There was a no significant gender difference in terms of earnings. fied rates. This is because deductions were routinely made to cover the cost of accommodation, food, and registration $^{25}$ (see also: Arnold 2004; FTUB/Robertson Jr. 2006). The cost of accommodation, which is frequently a mattress in a shared room of a dormitory in the factory compound, can range from 50 to 300 baht per month. Alternately, it can take the form of working in lieu of payment, which often means having to work without pay on the evening shift between 5 p.m. and 9 p.m. to cover the cost of accommodation.

The cost of obtaining a work permit is shouldered by the workers through deductions from their salary over several months. Those who are not eligible for a permit for whatever reason still have money deducted from their earnings for the 'immigration fee'. This can also cover a fund to bail (or bribe) the workers out when they are arrested, but many employers levy this charge simply to cover the fact that they (the employers) are taking a risk by employing illegal migrants, though there is little evidence that there are real risks of penalties in doing so. Some workers report that there is a further deduction of between two and three per cent of their earnings, and that they are not aware of the reasons for deduction, or that it is to cover something called a 'landing fee'. ${ }^{26}$

The working hours are very long in the border factories, which leaves the women hardly any time for themselves. A typical working day is 8 a.m. to 5 p.m. and then 6 p.m. to 9 p.m., with two thirty-minute breaks, although if there is a lot of work, shifts can extend late into the night. In theory, there is a six-day week, with a free day on Sunday, but many workers reported that they only get one or two days holiday per month. Usually these fall just after payday, and most of the time is spent arranging to send money and goods to their families back home.

Most women workers we spoke to organized their own shopping and cooking. During their breaks, they were able to buy vegetables from informal sellers in front of the factory, and then cook food using the rudimentary facilities in their dormitories. They had to

25 According to many of our informants, deductions were made for registration fees, whether or not the worker was officially registered and incurred costs for this.

26 This is a term used by a number of migrant workers we interviewed but does not appear to correspond to any recognised category. The workers said it was a fee that they had to pay to be allowed to work in the factories that was above the charges they paid to agents who arranged their transportation and introduction to the factories, though it is not clear to whom they paid this fee. 
fit in other tasks including cleaning, laundry, and bathing within their break periods. Women complained that their working day was too long, and married women and those with children ${ }^{27}$ especially complained of having extensive extra, gendered responsibilities in addition to their work in the factories, and of being unable to take sufficient rest, let alone have any free time for leisure activities.

It is clear that women experience stress from the pressure to ensure family survival with low wages and long working hours. According to a recent interviewee in Mae Sot:

Last week I could not sleep at night and I lost my memory. I could not remember where I put my things. I put money in front of me and I was searching for that money. Then, I told my problem to an Indian-Burmese woman who came to our compound and she gave me two tablets of medicines to sleep well. Oh, that it was very good for me and I slept very well for two nights and I became normal from that day. The woman said not to take these kinds of sleeping tablets every day (Interviewed on 23 April 2009).

The accounts by these women indicate that the responsibility for their well-being often rests solely on their own shoulders; but added to this is the burden of care and family support for family members. It would seem that their ability to reproduce their own labour power on a daily basis is compromised not just by the exploitative conditions of their employment, but also by the gendered restrictions on their mobility, as well as their responsibilities for their family's wellbeing.

\subsection{Gender and Generational Reproduction of Labour Power}

According to Mushakoji (2003: 152), "victims of exploitative migration have insecurity built into their biological reproduction as well as in provisioning for their caring needs". Although Mushakoji's research concerns migrant sex workers in Japan, the point applies well to migrant women in our study, who struggle with the demands of both biological and generational reproduction.

The factors that restrict both migrant women's and men's mobility conspire with employer practices

27 Among the semi-structured questionnaire survey respondents in Mae Sot (who were all ever married), $64 \%$ of them had some of their children living in Thailand while a similar number of respondents had some of their children living in Burma. to restrict migrant women's reproductive choices. The women migrant workers we had contact with reported that even though they are aware that Thai law allows a period of paid maternity leave among other rights for legally registered workers, this is rarely granted by the factory management. Some make limited adjustments for pregnant women by shifting them to a workplace with lighter work or allowing them to come five minutes later than other workers. But in practice there are real problems for women workers who become pregnant. Some women workers did talk about the possibility of maternity leave, but this usually meant only that they could return to work after the baby is delivered. Since they are paid daily wages, this means a loss of all income whilst they are absent. A number of women reported that their economic situation made it very difficult for them to take leave to have children.

Organizations working with migrant workers in Mae Sot also reported that many migrant women who became pregnant were forced into the difficult decision of seeking a termination, a situation that is supported by other research (Maung/Belton 2004). A significant proportion of women respondents in our study feared that pregnancy would make it more difficult to find or retain work in the factories, which they needed to earn remittances for family back home. ${ }^{28}$ But abortion among migrant women workers in Mae Sot is a dangerous undertaking. Dr Cynthia Maung reported that the rate of abortion amongst the Burmese women attending the Mae Tao Clinic ${ }^{29}$ had increased over the previous four to five years, and by 2007 some fifty-five per cent of maternal mortality was caused by post-abortion complications. ${ }^{30} \mathrm{~A}$ further deterrent to pregnancy is that many employers do not allow babies or children to stay in the workers' dormitory. Although some are able to find accommodation in the town, the demands of shift work and the lack of childcare facilities, as well as the other factors restricting women's mobility discussed above, all make it difficult for women to combine pregnancy and infant care with continuing employment in Mae Sot's factories.

28 Other reasons for abortion included abuse and abandonment by their partners, contraceptive failure, and pressure from relatives, friends, and husbands (Maung/ Belton 2004).

29 This clinic was founded and is directed by Dr Cynthia Maung, and provides free health care for refugees, migrant workers, and other individuals crossing the border from Burma to Thailand. See at: <http://www.maetaoclinic.org>. 
For those who continue with their pregnancy, another difficult decision concerns whether to have the child in Thailand or in Burma. According to Dr Cynthia Maung, compared to the previous five years, in 2007 more migrant women were delivering their babies in Mae Sot rather than choosing to return home to Burma for their confinement. ${ }^{31}$ This is not because they perceive any improvement in the relative attractions of staying in Thailand in the long term. It is rather because the insecurity of their employment and the irregularity of the wages from their factory employment mean that they can no longer commit the resources of time and money to returning home. This view was also supported by the testimonies of our interviewees who reported that the cost of delivering in the Mae Tao Clinic is cheaper even for non-registered migrant workers than returning to give birth in Burma, and others who said that the equipment in Thailand is better because of the general deterioration in the health services in Burma.

As we have indicated above, women migrant workers incur hardship with pregnancy and childbirth; these hardships in fact go well beyond immediate birth and infancy. Mothers are responsible for a child's welfare until the child is of working age or beyond, and older women frequently take responsibility for parents and other relatives who are beyond working age. For many Burmese migrant women workers in Thailand, the generational reproductive responsibility extends beyond bearing and rearing their own children. The very limited employment and income-generating opportunities faced by many households in Burma (Fink 2009) mean that the decision to migrate to Thailand is frequently a family strategy involving immediate and continual responsibility for the family back home. So the generational responsibilities of

30 This figure was provided by Dr Cynthia Maung during an interview on 9 July 2007. Maung/Belton (2004) reported that of the fourteen pregnant women who died in the Tak hospital in 200I/02, none were Thais and three of the deaths (twenty-two per cent) were due to unsafe abortions. Available statistics indicate that there is a much higher maternal and peri-maternal mortality rate for migrant workers than for the general Thai population. Thailand's maternal mortality rate was relatively low in international terms: 44 per 100,000 live births in 2000 (WHO 2006). Around five thousand pregnant Burmese women register at Mae Tao clinic each year. The cost of an illegal abortion is $1000-4000$ baht (Buschmann 20II).

31 Interview, 9 July 2007. women workers include the responsibility to remit money to their families in Burma.

Our research, together with other studies (see Kittisuksathit 2009), indicates that single women universally send money to their parental homes. Most women migrants report that the obligation to support birth families financially continues after marriage; in contrast, men are more likely to discontinue remittances after marriage. The single women respondents we interviewed for our research reported remitting quite large sums to their families in Burma, despite earning very low wages, which as we have seen are then further depleted by a range of deductions. One respondent who said she earned between 2000 and 4000 baht per month reported remitting between 2000 and 3000 baht per month, leaving almost nothing to cover her own living expenses in Mae Sot, a pattern common among women we spoke to. The semistructured questionnaire also shows that women do not always reduce remittances even when their income decreases or they become unemployed. Forty per cent of women respondents in Mae Sot said that they would reduce remittances when their income decreased, while more than forty-eight per cent of men respondents said the same. During the global economic crisis in 2008-9, both women and men decreased their remittances from the level of previous years (when they remitted nearly Io, ০o० baht per year), but women respondents still maintained their remittances at an average of 8,702 baht per year, while remittances from men dropped to 7,510 baht.

Another ongoing responsibility that women who have children have to deal with is decisions about how and where to care for these children. Whilst some women decided to withdraw from their jobs if keeping the child was not compatible with work, others reported changing their employment to a workplace where they were allowed to have their infant with them in the dormitory, if not in the factory. Some women are able to find older Burmese women in Mae Sot to care for their children in Thailand, but as the cost of paying caregivers to look after their children is expensive for low-waged women, this is normally the last resort or only a temporary arrangement. Many of our informants instead sent or took their children back home to Burma to be cared for by grandparents or other female relatives. Another common strategy is to support other relatives - usually parents or older siblings - to come to Mae Sot from Burma to care for infants. However, childcare by parents and other relatives coming to Thailand is an available option only for those who are relatively settled in Thailand, espe- 
cially those who are registered, or have access to better housing, or both. Table 4.2 summarizes the responses of our interviewees concerning arrangements made by Burmese migrant workers in Mae Sot to provide for the care of their children.

Table 4.2: Childcare patterns for children under six years old for respondents in Mae Sot who had had a child after coming to Thailand. Source: Questionnaire survey.

\begin{tabular}{|c|c|}
\hline & $\begin{array}{l}\text { Number of } \\
\text { respondents }\end{array}$ \\
\hline Childcare by oneself in Thailand & $19(9.2 \%)$ \\
\hline Childcare in Thailand with paid caretaker & $18(8.7 \%)$ \\
\hline $\begin{array}{l}\text { Childcare by oneself in Thailand then send } \\
\text { child to Burma }\end{array}$ & $78(37.7 \%)$ \\
\hline $\begin{array}{l}\text { Childcare by oneself in Thailand then invite } \\
\text { parents to come to Thailand }\end{array}$ & $96(46.4 \%)$ \\
\hline Childcare in Burma & $31(15.0 \%)$ \\
\hline Total number of respondents & $207(100 \%)$ \\
\hline
\end{tabular}

Note: This analysis is only for the 207 respondents who had their first child after they came to Thailand. It includes all the children of these migrant workers. Thirtyone of the respondents had two children and two had three children.

As table 4.2 indicates, arrangements for the care of migrant workers' infants and children reflect the relative economic security and family situation of the migrant workers, and are frequently amended in response to changing circumstances. Depending on their situation, which itself is subject to change, arrangements for childcare reflect the available resources. For example, one informant's parents came to Myawaddy (on the Burmese side of the border) when her child was two months old. But the informant found travelling across the border to visit them on her day off was expensive, and the parents also incurred the costs of obtaining residence permits since they were not residents of Myawaddy. After a few months she brought the child back to Mae Sot to be cared for by a neighbour, and when it was eight months old, she arranged for her parents to come to Mae Sot to provide ongoing care.

Another woman's account illustrates the complexities involved in making appropriate arrangements for infants:

I got pregnant while I was working there. ... I worked till eight months of pregnancy. When I cannot work they gave me leaves but no payment. ... When my baby got 4 months old, I went back to Burma with her to bring back my elder son, eight years old during his school holiday to look after my last baby. After three months, as my eldest son needed to attend the school, I sent him back to Burma, went with my little baby again and brought back my mother with me to look after my little baby. I moved the job to home factory, where I can stay with my baby. I kept my baby near me in the cradle while I was working. I can give breast feeding to her while I was working (Interviewed 22 March 2008).

Decisions about childcare are always complicated, and the costs fall on the shoulders of the women migrants themselves. Some women are lucky to have better-off parents or siblings back home, who will be able to give good care to their children, but in some cases this arrangement breaks down. One of the migrant workers interviewed reported that her mother was responsible for the care of five grandchildren including this worker's own daughter. She remitted 40,000 kyats $^{32}$ per month, which covers less than half of the minimum estimated cost of such a household, although other siblings probably made a contribution. But her ageing mother was unable to manage all five children, and this worker had to bring the child back to Mae Sot where she boarded her with a non-related Burmese women. Another migrant woman reported that she had to leave her baby with her mother, in spite of her mother's health problems. Another migrant woman who had left her baby in the care of her mother-in-law reported that when her mother-in-law passed away, she had to make an arrangement with a neighbouring woman in her home village to take care of her child.

A further aspect of generational reproduction is the education of children. Most of the women interviewed had high expectations for the education of their children. Even when infants are sent to Burma for care, many of them are brought back to Thailand once they reach school age. The Thai education system is, in theory, generous to migrant residents and a government decision in 2000 indicated that all children within the country regardless of nationality and status are permitted to attend Thai schools. However, in practice few do; attending school requires a household registration, which is rarely available to migrant children except when their parents have good connections to some Thai citizens.

In practice the majority of Burmese families in Mae Sot send their children to the numerous migrant schools in the town, which are supported by the overseas diasporic communities and by international

32 I USD= 950 kyat. 
organizations. ${ }^{33}$ Some Burmese parents consider the quality of the migrant schools in Thailand to be better than the alternatives; many schools recruit from nonmigrant families in the bordering provinces. They hope that the trilingual system of education - Burmese, English, and Thai - will be advantageous to their children's futures wherever that may be. One of the women migrant workers remarked:

I will keep my children in the school here until they get some level of education for their life to work here. At least if they can write and speak Thai and Burmese well, they can get good jobs here (Interviewed on 8 May 2008).

Where to raise the children is always a difficult decision and one that causes a great deal of anguish for women who are not just concerned about their children's access to education, but who also have the responsibility of maintaining their kin networks, even from across the border:

After giving birth, I left the children with my parents, but since my mother came to Mae Sot, I left my children with my parents-in-law. Now I am thinking of bringing my children to Mae Sot. My mother is already looking after three grandchildren [her sister's children]. I do not want to burden my mother. But I want to be with my children and give children good education. But my work is unstable, and I am afraid that if I do not have job, I cannot afford children's education in Mae Sot. Then, I have to send the children back to Burma, and that will affect their education. I also have to convince my mother-in-law who is now attached to the grandchildren (Interviewed on 23 March 2008).

But whatever decision is made, it is unlikely to be permanent, sustainable, or satisfactory. And as we discuss below, the situation is becoming more problematic for migrant workers and their children. Moreover, the opinions of Thai officials and the public are often hostile to facilitating the education of migrant children in Thai schools. In this excerpt from a newspa-

33 Except for the migrant schools and nurseries organized by NGOs and Buddhist monks, care of the children of migrant workers depends directly on the individual agency of the workers, especially of the women workers and their female relatives. In general the more collective actions undertaken by NGOs and trade unions are concerned with the migrant workers' working conditions and legal status. More recently there have been calls from Thai unions and human rights organizations for more attention to be given to the issue of the childcare of migrant children, but the limited resources and constrained situation of the migrant workers themselves make it difficult for these workers to organize collective childcare in Mae Sot. per report (Ekachai 2007), a police officer expresses an attitude that is widespread in the country:

Having migrant children studying in the town centre is also not appropriate, due to potential security problems. For safety, the migrant population should be in a restricted zone under state control. Also, if they want to study, their older peers should do the teaching, not our people.... I cannot see how educating these children can benefit our country in any way. We have to think about the burden society must shoulder if these children decide to stay on. ${ }^{34}$

A further aspect of women's responsibility for generational reproduction concerns access to health care for family members as well as themselves. Health services especially in the border areas are also in theory relatively generous to registered migrant workers, since they, like other low-paid workers in Thailand, can use the universal health care scheme to access health care ${ }^{35}$ although government officials fear the burden this places on Thai public services and finances (Archavanitkul 2002). However, the non-registered migrants or family dependents of registered migrant workers have difficulties accessing this service, which requires its own identity documents. In practice, migrant workers rarely attend public hospitals or health facilities; instead they tend to purchase medication directly, or attend NGO- or diaspora-funded clinics such as the Mae Tao clinic wherever available. Migrant workers are rarely aware of their entitlements to public health services in Thailand, and their restricted mobility and lack of knowledge of the Thai language further limits their possibility of using such services (Ling 2007). Many workers report returning to their home country if they or their family members have serious or chronic illnesses, and women's earnings are frequently central to the family's ability to access health care in Burma.

34 Recent research by this project indicated there was ideological resistance by teachers to accepting the children of migrant workers in their schools, as well as bureaucratic and financial obstacles, despite clear government policy for integration.

35 The scheme was launched in 200I, and was called a 30 Baht Universal Health-care Coverage Policy. Those who were not covered by any other health insurance scheme were given a card that would allow them to use health services with a payment of 30 baht per visit. In 2007 , it was changed to be free of charge. However, migrant workers were still required to pay the 30 baht. 


\subsection{Women Migrant Workers in Mae Sot's Export Factories: Negotiating Political, Economic, and Gendered Constraints}

As the economic situation in Thailand worsens as the result of the current global credit crunch and the fall in export demand for garments and textiles, the situation of migrant workers is uncertain, increasing the difficulties faced by women migrants seeking to secure the well-being of their children and other family members.

Changes in the registration of irregular migrant workers in Thailand referred to above indicate that the Thai state is unlikely to take on additional costs associated with the supply and employment of migrant workers. If for any reason the situation of a migrant worker were to change - for instance, if she were to lose her job or become unable to work due to health or other reasons, or if she became pregnant under the terms of this agreement the worker would be repatriated. Under the previous registration scheme as well as the current temporary passport and work permit scheme, documentation and entitlement applies only to individual "workers" with no provision for families or dependents, which would include both existing children and adult relatives. Strict enforcement of these terms would disallow the strategies currently employed by many migrant workers to meet their reproductive responsibilities by bringing in older relatives to provide childcare for children, or bringing elderly dependants to Thailand to support them there.

Ongoing economic difficulties in Thailand also raise the fear that hostility against migrants will be boosted for reasons of political expediency. A study by the Institute of Asian Studies (ISA), the Thailand Development Research Institute (TDRI) and Institute for Population and Social Research (IPSR) (2003) reported that hostility from the business community is well established. Opposition focused not only on the potential for migrants to displace Thai citizens in the economy, but also on the claim that migrants 'pollute' local society. Sizeable proportions of those interviewed considered that migrants were a threat to national security, life, and property, and that they carry transmittable diseases. As we have seen above, male migrants have long been seen as a security threat and blamed for social and political unrest. Women migrants are currently being constructed as the cause of a 'population explosion'. When the former Deputy Prime Minister Sonthi Boonyaratkalin visited a Burmese migrant community near Bangkok in November
2007, his response to the presence of pregnant migrant women and migrant children was that migrants should be prohibited from giving birth in Thailand. ${ }^{36}$

Such statements reflect the ongoing ambivalence of the Thai government towards the conflicting objectives of meeting demand for migrant labour, which may well increase during the current recession ${ }^{37}$, and addressing popular fears of migrants as threats to national employment and security. This ambivalence reflects the tensions resulting from the ongoing harassment of migrant workers and the policy of confining migrant workers to the border zone areas (FTUB/ Robertson Jr. 2006).

However, as we pointed out in the introduction, it is important to understand how migrants negotiate the structural constraints they face, not least in securing the care and well-being of their children whilst they continue to engage in waged work to support their families. Our research has indicated that there are many ways that migrant women navigate the controls and exploitative conditions imposed by the state and employers and mobilize resources to meet their reproductive obligations in a hostile and changing environment. In spite of the attractions of bearing and raising their children in their home country, which would in most cases make it more possible to obtain Burmese nationality for their children and to utilize family support and networks, as well as the difficulties discussed above in accessing health services and childcare in Mae Sot, women migrant workers are increasingly disinclined to send their children back to Burma.

Migrant women, especially mothers, juggle their care responsibilities across the border, and between different women (usually kin) in order to manage their childcare responsibilities. Their approach to the education of their children is equally pragmatic, weighing the pros and cons of the different locations and opportunities for education in the two countries. Constrained by their irregular status, their exploitative work experiences, and the institutional constraints on their mobility and entitlement, women are demonstrating remarkable resilience and making decisions that reflect their own aspirations for the future of

36 "Sonthi orders that foreign workers need to deliver children outside the country", in: Komchat Luk, I5 November 2007.

37 According to, for example, a report in The Economist on I9 March 2009: "Burmese migrant workers in Thailand - Myanmar's overflow”. 
themselves and their children. They acquire familiarity with the local area, and in time are less constrained by the restrictions of employers, authorities, or peer groups. They make difficult and complicated decisions about their own health issues and the care and well-being of their children and other family members. For these women, the border increasingly becomes less a division between absolutes - opportunities in Thailand and oppression in Burma - and more a porous contour across which they constantly strategize, moving themselves, their money, and their families to the location which would seem to offer the best short- or long-term advantages.

\subsection{Conclusion}

This case study has argued that even in increasingly unstable circumstances women migrant workers have to continue to balance their reproductive responsibilities as mothers and daughters with their ongoing role as wage workers and economic providers, often managing complex transborder care arrangements. Industrial strategy meanwhile is made on the basis of geopolitical interests or immediate economic crises with little or no concern about the process that delivers cheap and productive workers in the bodies of migrant workers crossing the river from Burma. As women continue to shoulder responsibilities for organizing the place and manner in which babies are born and cared for, for the economic and emotional support of families, and for the daily and future health and education of their children and other family members, women's agency and creativity will be tested. Whilst all women's agency is operated within constraints, in the case of Burmese migrant workers the constraints are more restrictive than in most other

\section{References}

ACMECS, 2004: "Ayeyawady-Chao Phraya-Mekong economic cooperation strategy", in: ACEMECS Ministerial Retreat, Krabi, Thailand, 2 November, at: <http:// www.acmecs.org/index.php>.

Amnesty International, 2005: "Thailand: the plight of Burmese migrant workers", in: AI Index, June, (New York: Amnesty International).

Archavanitkul, Kritaya, 2002: Research Direction and Knowledge About Migrant [in Thai] (Bangkok: Institute for Population and Social Research, Mahidol University).

Arnold, Dennis, 2004: The situation of Burmese migrant workers in Mae Sot, Thailand. Working Papers Series, No. 7I (Hong Kong City: University of Hong Kong). contexts. But their situation illustrates the ways in which the globalization of the market is linked with the international division of productive as well as reproductive labour, which takes place across the borders between poor countries in the global South, as well as between countries of the richer North and the poorer global South. Importantly, as this case study illustrates, this international division of labour does not just concern women who migrate to take up jobs as domestic servants and other care workers; it also concerns the way in which women factory workers manage and support the reproduction of their own labour power and that of their families across the borders between often hostile and inhospitable states.

Women migrant workers, without support from the receiving state and even with the harsh treatment that they experience in childbirth and childcare, have tried to negotiate the spaces offered by the (limited) state's provision of health and maternity care as well as the lax border controls between Mae Sot and Myawaddy to manage their reproductive responsibilities whilst continuing to do their paid work in garment and textile factories. This often involves the continuous shifting of children and caretakers back and forth across the border to manage childcare. This might not be a positive reproductive bargain over division of responsibility with the state, but it does necessitate a certain level of negotiation with the state by circumventing the obstacles that they face in terms of their reproductive activities. And whilst the current international celebration of political changes within Burma might offer improvements in the rights and services available to Burmese workers, it is unlikely that the conditions and prospects of migrant workers in Thailand will be improved in the foreseeable future.

Arnold, Dennis, 2006: Capital Expansion and Migrant Workers: Flexible Labor in the Thai-Burma Border Economy (MA Dissertation, Salaya, Thailand: Mahidol University, Faculty of Graduate Studies).

Asian Human Rights Commission, 2005: "Update on urgent appeal" (Hong Kong: Asian Human Rights Commission, I6 September).

ARCM (Asian Research Center for Migration); IPSR (Institute for Population and Social Research); TDRI (Thailand Development Research Institute), 2004: "Thailand: improving the management of foreign workers: case studies on five industrial sectors", prepared for IOM (International Organization for Migration); ILO (International Labour Office); IOM, Mission with Regional Functions (Bangkok, Thailand). 
Barimbun, Anchana, 2006: "Future of Thai textile: crisis or opportunity", paper presented at the Situation of Textile Industry Two Years after Trade Liberalization, 20 December, at: <www.thaitextile.org/th/backup/PR/ $061220 / p p t>$.

Buschmann, Verena, 20II:"Thailand: backstreet abortions on rise at border among illegal migrant workers", European Pro-choice network, I9 July; at: <http://europeanprochoicenetwork.wordpress.com/page/II/> (2I May 20I2)

Caouette, Therese, M., 200I: Small Dreams Beyond Reach: The Lives of Migrant Children and Youth Along the Borders of China, Myanmar and Thailand, A Participatory Action Research project of Save the Children UK (London: Save the Children).

Chalamwong, Yongyuth, 2004: "Government policies on international migration: illegal workers in Thailand", in: Ananta, Aris; Arifin, Evi Nurvidya (Eds.): International Migration in Southeast Asia, (Singapore: Institute of Southeast Asian Studies), 352-373.

Chalamwong, Yongyuth; Amornthum, Somchai, 2002: Thailand: Improving Migration Policy Management with Special Focus on Irregular Labour Migration: Analysis of Thai Labour Market (Bangkok: Thailand Development Research Institute Foundation).

Chulalongkorn University, 2003: "Migrant workers from Burma and Thailand: policy review and protection mechanisms, commemorating Io years of policy governing migrant workers from Burma”, Proceedings of a seminar on Reviewing Policies and Creating Mechanisms to Protect Migrant Workers (Bangkok: Chulalongkorn University, 2I February).

Ekachai, Sanitsuda, 2007: "A place to learn”, in: Bangkok Post, 26 June.

Elson, Diane; Pearson, Ruth, I98r: "Nimble fingers make cheap workers", in: Feminist Review, 7 (Spring): 87I07.

EXIM (Export-Import Bank of Thailand): “Thailand's international trade”, at: EXIM website, Thailand, 24 August; at: 〈http://www.exim.go.th/eng/economic_information/ inter.asp>.

Fink, Christina, 2009: Living Silence in Burma: Surviving Under Military Rule, second edition (Chiang Mai: Silkworm Books; London - New York: Zed Books).

Folbre, Nancy, 1994: Who Pays for the Kids? Gender and the Structures of Constraint (New York - London: Routledge).

FTUB (Federation of Trade Unions Burma), 2004: Brief Report on Child Migrant Workers from Burma in Thailand, Case study - Mae Sot (Bangkok, Thailand: FTUB).

FTUB, Migrants Section; Robertson Jr., Phil S., 2006: The Mekong Challenge - Working Day and Night: The Plight of Migrant Child Workers in Mae Sot, Thailand. Mekong Sub-Regional Project to Combat Trafficking in Children and Women, International Programme on the Elimination of Child Labour (Bangkok: International Labour Organization).
Hochschild, Arlie, 200I: "Global care chains and emotional surplus value", in: Hutton, Will; Giddens, Anthony (Eds.): On the Edge: Living with Global Capitalism (London: Vintage).

Huguet, Jerrold W., 2007: "Thailand's policy approach to irregular migration”, mimeo, May, in: Martin, Paul (Ed.), 2007: The contribution of migrant workers to Thailand: Towards policy development (Bangkok: International Labour Office).

Huguet, Jerrold W.; Punpuing, Sureeporn, 2005: International Migration in Thailand (Bangkok: International Organization for Migration).

Hveem, Petter; Than Doke, 2004: "Hidden exploitation: Burmese migrants in Thai garment factories - hidden sub-contracting by Tommy Hilfiger Corporation and other brands, Mae Sot, Thailand”, third draft version, April (Bangkok: Norwegian Church Aid).

Institute of Asian Studies, Chulalongkorn University; TDRI (Thailand Development Research Institute); IPSR (The Institute for Population and Social Research); Mahidol University, 2003: Research project: demand of migrant worker in Thailand 2003-2005, submitted to the National Security Council, Prime Minister's Office, October.

Kittisuksathit, Sirinan, 2009: "Remittance-sending behaviour among migrants from Myanmar, the Lao PDR and Cambodia”. Paper presented at the International workshop on gender, migrant workers and citizenship in Greater Mekong Sub-region: Economic and political perspectives for a world in crisis, Asian Institute of Technology, Thailand, I-3 June.

Kusakabe, Kyoko; Pearson, Ruth, 20I0: "Transborder migration, social reproduction and economic development: A case study of Burmese women workers in Thailand", International Migration, 48:6, I3-43.

Kusakabe, Kyoko; Pearson, Ruth; Naw Eh Mwee; Phadungkiati, Lada, 2008: Analyzing Linkages Between Migrant Workers, Commodity Chains and Regional Development in Mae Sot and Migrant Workers' Workshop on Locating Ourselves in the Economy and Society (Bangkok - Pathumthani: Asian Institute of Technology).

Ling, Deborah, 2007: Burmese Migrant Workers' Access to Health Care Services in Thailand (M.Sc. thesis, Bangkok - Pathumthani: Asian Institute of Technology).

Martin, Philip, 2007: The contribution of migrant workers to Thailand: Towards policy development (Bangkok: International Labour Office).

Martin, Philip; Asian Research Center for Migration; Institute for Population and Social Research; Thailand Development Research Institute, 2004: Thailand: Improving the Management of Foreign Workers (Bangkok: International Labour Office; International Organization for Migration).

Mackintosh, Maureen, I984: "The sexual division of labour and the subordination of women", in: Young, Kate; Wolkowitz, Carol; McCullagh, Roslyn (Eds.): Of Mar- 
riage and the Market: Women's subordination in international perspective (London: Routledge - Kegan Paul).

Maung, Cynthia; Belton, Suzanne, 2004: Working Our Way Back Home: Fertility and Pregnancy Loss on the Thai Burma Border (Melbourne: Melbourne University; New York: Open Society Institute).

Mushakoji, Kinhide, 2003: "Social reproduction of exclusion: exploitative migration and human insecurity", in: Bakker, Isabelle; Gill, Stephen (Eds.): Power, Production and Social Reproduction: Human In/Security in the Global Political Economy (Basingstoke: Palgrave Macmillan).

Myint Wai, Bhumiprabhas; Subhatra;Kerdmongkol, Adisorn (Eds.), 2004: A Memoir of Burmese workers: From Slaves Labour to Illegal Migrant Workers (Bangkok: Thai Action Committee for Democracy in Burma [TACDB]).

Nagar, Richa; Lawson, Victoria; McDowell, Linda; Hanson, Susan, 2002: "Locating globalization: feminist (re) readings of the subjects and spaces of globalization", in: Economic Geography, 78,3: 257-284.

Ong, Aiwha, 2004: "Graduated sovereignty in South-east Asia”, in: Theory, Culture and Society, I7,4: 55-75.

Osawa, Mari, 20II: Social security in contemporary Japan: A comparative analysis, (London: Routledge).

Parreñas, Rachael, S., 200I: Servants of Globalization: Woman, Migration, and Domestic Work (Stanford Stanford University Press).

Pearson, Ruth, 1997: "Renegotiating the reproductive bargain: Gender analysis of economic transition in Cuba in the 1990s", in: Development and Change, 28,3: 671-705.

Pearson, Ruth; Kusakabe, Kyoko, 20I2a: "Who cares? Gender, reproduction and care chains of Burmese migrant factory workers in Thailand”, in: Feminist Economics, I8,2: I49-I75.

Pearson, Ruth; Kusakabe, Kyoko, 20I2b: Thailand's Hidden Workforce: Burmese Migrant Women Factory Workers (London: Zed Books).

Pearson, Elaine; Punpuing, Sureeporn; Jampaklay, Aree; Kittisuksathit, Sirinan; Prohmmo, Aree, 2006: Mekong Challenge - Underpaid, Overworked and Overlooked: The Realities of Young Migrant Workers in Thailand, Volume One, Mekong Sub-regional Project to Combat Trafficking in Children and Women, (Bangkok: International Labour Office).

Pollock, Jackie, 2006: "Cross-border migration: Burma-Thailand”. Paper presented at Asian Consultation on Gender, Migration and Citizenship, Asia Research Institute, National University of Singapore and International Development Research Centre, Singapore, 25-26 October.

Punpuing, Sureeporn, 2006; The Mekong Challenge: Underpaid, Overworked and Overlooked - The Realities of Young Migrant Workers in Thailand, Volume Two, Mekong sub-regional project to combat trafficking in children and women; International Programme on the Elimination of Child Labour (Bangkok: International Labour Organization).
Rattanarut, Nara, 2006: "Immigration management and administration in Thailand", in: Martin, P. (Ed.): The Contribution of Migrant Workers to Thailand: Towards Policy Development (Bangkok: International Labour Office).

Sassen, Saskia, 2008: “Two stops in today's new global geographies: shaping novel labor supplies and employment regimes", in: American Behavioural Scientist, 52,457: 457-496.

Sciortino, Rosalia; Punpuing, Sureeporn, 2009: International Migration in Thailand (Bangkok: International Organization for Migration).

Silvey, Rachel, 2004: "Power, difference and mobility: feminist advances in migration studies", in: Progress in Human Geography, 28,4: 490-506.

Sparke, Matthew; Sidaway, James D.; Bunnell, Tim; GrundyWarr, Carl, 2004: "Triangulating the borderless world: geographies of power in the Indonesia- Malaysia - Singapore growth triangle", in: Transactions of the Institute of British Geographers, NS29: 485-498.

Thammasak, Anchalee, I998: Workers' Situation and Needs for Remuneration: A Comparative Study Between Thai and Foreign Workers in Samutprakan Province (Master's dissertation, Bangkok: Mahidol University [in Thai]).

Thapan, Meenakshi, 2006: "Series introduction", in: Anuja Agrawal (Ed.): Migrant Women and Work, Women and migration in Asia, Volume 4 (New Delhi: Sage Publications): 7-I7.

The Economist, 2009: "Burmese migrant workers in Thailand - Myanmar's overflow”, I9 March.

Traitongyoo, Krongkwan, 2008: The Management of Irregular Migration of Irregular Migration in Thailand: Thainess, Identity and Citizenship ( $\mathrm{PhD}$ dissertation, Leeds: University of Leeds, School of Politics and International Studies).

Tsuneishi, Takao, 2005: The regional development policy of Thailand and its economic cooperation with neighboring countries. Discussion Paper, No. 32 (Chiba: Institute of Development Economies, Japan External Trade Organization).

Valentine, Gill, I989: “The geography of women's fear", Area, 2I: 385-390.

WHO (World Health Organisation), 2006: "Mortality country fact sheet" (Geneva: World Health Organisation)

World Vision; Asian Research Center for Migration, 2003: Research report on migration and deception of migrant workers in Thailand (Bangkok: Chulalongkorn University).

Wright, Melissa W., 2006: Disposable Women and Other Myths of Global Capitalism, (New York: Routledge).

Yeates, Nicola, 2005: Global Care Chains: A Critical Introduction (Geneva: Global Commission on International Migration).

Yeoh, Brenda S.A.; Huang, Shirlena, I998: "Negotiating public space: strategies and styles of migrant female domestic workers in Singapore", in: Urban Studies, 35,3: 583602.

Open Access. This chapter is distributed under the terms of the Creative Commons Attribution Non-commercial License, which permits any noncommercial use, distribution, and reproduction in any medium, provided the original author(s) and source are credited. 